\title{
Colour naming
}

\author{
Ebru Şahin Ekici, Cengiz Yener, Nilgün Camgöz* \\ Department of Interior Architecture and Environmental Design, Faculty of Art, Design and Architecture, Bilkent University, 06800 Bilkent, \\ Ankara, Turkey
}

Available online 25 July 2005

\begin{abstract}
An experimental study exploring colour ranges corresponding to different colour names has been conducted. Available colour terms in Turkish language have been identified and the most frequently known or used colour terms have been attained. Using the Munsell Color System, colour ranges reflecting the colour naming and colour perception of Turkish people, have been constructed for each colour term. The discussion of the findings and observations during the research are also included.
\end{abstract}

(C) 2005 Elsevier Ltd. All rights reserved.

Keywords: Colour naming; Colour perception; Colour terms

\section{Introduction}

Naming of colours could be considered as subjective evaluations. Attitudes to colours are formed to a greater part by early childhood learning processes and thus, are culturally imposed. People learn to use necessary terms in order to have more specific descriptions. Colours serve as informative cues about the surrounding environment; therefore, to some extent they are also common symbols for different concepts.

An experimental research has been conducted to investigate colour naming in Turkey. For each colour term, the effect of age, gender, occupation and the city of residence on colour naming were also examined.

\section{Objectives}

Basic colour names are the most frequently occurring colour words in language and literature. Non-basic colour names are used for making finer discriminations. Rather than using the general name of a colour (basic colour name), people derived more descriptive colour

\footnotetext{
*Corresponding author. Tel.: + 903122902429 ; fax: +903122664127 .

E-mail address: camgoz@bilkent.edu.tr (N. Camgöz).
}

names inspired from surface qualities of objects, animals and metals. These descriptive colour names are referred to as non-basic colour names.

The main objective of this study is to find the range of colour samples for each basic and non-basic colour name for Turkish people.

The study also tries to gain an insight into the following questions:

1. What are the colour names in Turkish language?

2. How do people perceive basic colours in Turkish language?

3. Which non-basic colour names are best known by Turkish people?

4. How much do people differ in selecting the colour sample when a specific colour name is assigned?

5. How is the response pattern in selecting non-basic colour names compared to basic colour names?

\section{Experimental procedure}

\subsection{Obtaining the list of colour names}

Definition of basic colour names differs among professionals depending on their field of study. A colour 
scientist would have yellow, magenta and cyan, the primary subtractive colours, and red, green and blue, the primary additive colours, as basic colour names. Many people in the general population would have red, orange, yellow, green, blue, indigo and violet as basic colour names since they are part of a rainbow. In this study, the main concern is the relation between colour stimuli and how these stimuli are named. Thus, it was necessary to look into ethnolinguistics in terms of colour naming. Ethnolinguists have chosen rules that differentiate basic from non-basic colour names only on the basis of linguistic considerations. In the World Color Survey, a general definition of basic colour terms has been added by Kay, Berlin and Merrifield as "the smallest subset of color terms such that any color can be named by one of them" [1]. Interpreting the data obtained from 98 different languages, Berlin and Kay listed the basic colour names from sequential and chronological appearance of colour names in all languages, which has psychophysical references and are results of human perception [2]. Basic colour names, excluding white, black and gray, listed in Berlin and Kay has been used in this study: red, green, yellow, blue, brown, purple, pink and orange [2].

Non-basic colour names were also used in this study. In order to identify most commonly used non-basic colour names, all the available colour names in Turkish language were collected from dictionaries, theses of language departments, literature and catalogues from painting, dyeing, textile and carpet industries. A total of 547 Turkish colour names were obtained. All the colour names in Turkish language are listed in Şahin [3].

An elimination procedure was applied to this initial list of all available colour names in Turkish language. All colour names with adjectives, qualifiers and modifiers attached to them; all colour names of foreign language origin; and all colour names belonging to professional/technical terminology were eliminated from the complete list.

Colour names with adjectives, qualifiers, modifiers attached to them (e.g., darkness/lightness, brightness/ paleness: pale blue "soluk mavi", dark yellow "koyu sar1", etc.) were eliminated as they were based on subjective perceptions. In any colour system, colours before or after a certain colour sample would be lighter/darker or brighter/more pale than that colour.

Colour names with foreign language origin (e.g., titian "titian", madder "madder", etc.) are not used by the native speakers of Turkish language in daily conversation. On the other hand, lemon yellow is "limon sarısı" in Turkish and navy blue is "lacivert", thus they both are words commonly used in everyday Turkish language. It should be noted that the whole study was conducted in Turkish, but for the sake of clarity all colour names were translated into English for this paper.

Colour names such as titanium white "titanyum beyazı", Rembrand red "Rembrant kırmızısı" require certain professional knowledge of technical terminology. A painter would possibly know the colour Rembrand red as the paint would be manufactured and sold with this name. Similarly, someone occupied with light measurement would understand titanium white clearly. However, these colour names are unfamiliar for the remaining part of the society. After eliminating colour names with the qualities mentioned above, a second list of 217 colour names was constructed.

This second list was tested among randomly selected participants in order to identify colour names known at least by $80 \%$ of them. One hundred and thirty-two people participated in this survey. From the distributed list, the participants eliminated the colour names they were not familiar with or had difficulty in identifying, visualising, remembering the exact colour that name imposed. After this elimination, a final list of eight basic and 24 non-basic colour names was constructed (Appendix A).

\subsection{The experiment}

Using a final list of 32 colour names and the Munsell Color System, responses from different cities in Turkey were collected.

Considerable care was taken in selecting these cities. The regions of Turkey are indicated by the Prime Ministry, State Planning Organisation (for further information see http://www.dpt.gov.tr/ing/ and www.dpt.gov.tr/dptweb/ekutup99/i199/i199.html\#ek).

For this experiment, native inhabitants of different cities among different regions of the country, representing local cultures that are least affected by other regions of Turkey were selected for the participant group. Of the 81 cities in Turkey data were collected in six: Ankara, Diyarbakır, Edirne, Isparta, Kayseri and Trabzon. These cities were selected as they do not have much immigration and thus have relatively unspoiled cultures [4]. Special attention was given to constitute the participant group from local people who lived from their birth till the end of their teens in that city.

Three hundred and twenty-two participants took part in the research. Besides the randomly selected participants, most of them were selected from companies, universities, institutions and high schools offering a colour-related profession after graduation in order to obtain the widest range in the selection of colour chips for colour names. The research included participants dealing with fine arts, design, architecture, embroidery and carpet weaving. 
All participants were tested in spaces illuminated by natural daylight from north. Experiment rooms in each city provided the same lighting conditions. The light source (natural daylight) was uniform through the entire testing time. Each participant was tested individually over a period of 10-20 minutes depending on his or her response speed.

Participants were asked to choose the Munsell colour sample among the samples laid down on a horizontal surface that matched most with the given colour term. First, the eight basic and then, the 24 non-basic colour names were assigned to the participants. The research question was stated in Turkish as "Așağıda ismi verilen renkleri size sunulan renk örnekleri arasından seçiniz" which would be translated as "Please pick up the colours named below, from the colour samples presented to you." Participants were instructed to pass over any colour, which they found difficult to match with the assigned colour name. They were also told that the test was not conducted to evaluate their personal abilities. Each participant selected the matched colour sample from the Munsell Color System after they were given the colour names one by one.

\subsection{Instruments}

The stimuli were the regular colour samples of the Munsell Book of Color, Glossy Finish Collection [5]. Forty pages of the original Munsell Color System was reduced to 10 pages by grouping and presenting four pages of the same hue on a single page. This grouping enabled the participants to see the preceding and following pages altogether. All the colour pages were placed on a horizontal surface large enough for participants to view all stimuli together (Fig. 1).

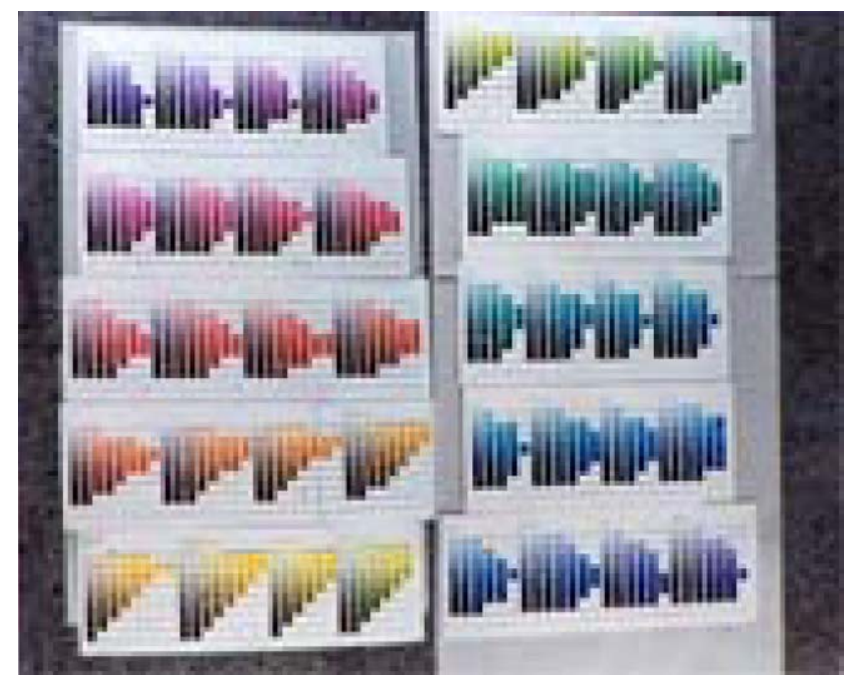

Fig. 1. Presentation of the colour samples.

\section{Findings}

SPSS software was used in the analysis of the collected data. Colour pages and colour samples of every single colour name were investigated by chi-square tests (Appendix B). Pearson correlation value was used to measure relationships between any colour pairs (Appendix C). Finally chi-square tests were applied to the collected data to investigate significance of gender, age, city of residence and use of colour in occupation (Appendix D).

Four different pages of the 10 hue ranges were coded into variables in order to enter the data in SPSS. Codes 1, 2, 3 and 4 were assigned for the colour pages 2.5, 5, 7.5 and 10 of each hue, respectively. Selected colour samples were entered into the computer by eliminating the "/" symbol between value and chroma.

\subsection{Analysis of basic colour names}

\subsubsection{Purple "Mor"}

There was no participant unable to identify the colour represented by the term "purple" ("mor"). The distribution of the responses varied in 11 colour pages, but main cumulation was in the $2.5 \mathrm{P}$ and $5 \mathrm{P}$ pages of the Munsell Color Book. Although the participants selected 22 different colour samples, only five of them were significant ( $p$-value: .0001, Appendix B).

The colour samples constituting the range for purple "mor" are (Appendix E, Fig. E.1):

\begin{tabular}{ll}
\hline Colour page & Colour sample \\
\hline $2.5 \mathrm{P}$ & $4 / 123 / 102 / 10$ \\
$5 \mathrm{P}$ & $4 / 123 / 10$ \\
\hline
\end{tabular}

\subsubsection{Pink "Pembe"}

All of the participants easily chose a colour sample when the name "pink" ("pembe") was assigned. Twenty different samples were pointed to represent pink "pembe". 2.5, 5 and 7.5RP pages were mostly used ( $p$ value: .0001, Appendix B).

The colour samples constituting the range for pink "pembe" are (Appendix E, Fig. E.2):

\begin{tabular}{ll}
\hline Colour page & Colour sample \\
\hline $2.5 \mathrm{RP}$ & $8 / 66 / 12$ \\
$5 \mathrm{RP}$ & $8 / 67 / 106 / 12$ \\
$7.5 \mathrm{RP}$ & $8 / 65 / 14$ \\
\hline
\end{tabular}

A relationship close to moderate has been found between the colour pages of pink-gypsy pink 
"pembe"-"çingene pembesi" ( $p$-value: .001, Appendix $C)$, and the colour pages of pink-rose "pembe""gül kurusu" ( $p$-value: .001, Appendix C). Thus, these colour pages show similarities during the identification process.

\subsubsection{Red "Kırmızı"}

Most of the participants chose a colour sample from the $7.5 \mathrm{R}$ page of the Munsell Color Book to represent red "kırmızı". Page 5R was also found important as $4 / 14$ sample of this page was significant in the choices for red "kırmızı". Red "kırmızl" is one of the colours that shows notable consensus in the selection of the representative sample ( $p$-value: .0001, Appendix B).

The colour samples constituting the range for red "kırmızı" are (Appendix E, Fig. E.3):

\begin{tabular}{ll}
\hline Colour page & Colour sample \\
\hline $5 \mathrm{R}$ & $4 / 14$ \\
$7.5 \mathrm{R}$ & $4 / 144 / 165 / 16$ \\
\hline
\end{tabular}

Colour choices for red "kırmızı" show similarities with choices for sour cherry "vişne çürüğü" ( $p$-value: .001, Appendix C).

\subsubsection{Orange "Turuncu"}

Participants noted 16 different colour samples for orange "turuncu". Pages 10R, 2.5YR and 5YR were frequently cited.

The colour samples constituting the range for orange "turuncu" are ( $p$-value: .0001, Appendices B and E, Fig. E.4):

\begin{tabular}{ll}
\hline Colour page & Colour sample \\
\hline $10 \mathrm{R}$ & $6 / 14$ \\
$2.5 \mathrm{YR}$ & $6 / 146 / 16$ \\
$5 \mathrm{YR}$ & $7 / 14$ \\
\hline
\end{tabular}

\subsubsection{Brown "Kahverengi"}

The response pattern for brown "kahverengi" shows very close distribution.

The colour samples constituting the range for brown "kahverengi" are (p-value: .0001, Appendices B and E, Fig. E.5):

\begin{tabular}{ll} 
Colour page & Colour sample \\
\hline $5 \mathrm{YR}$ & $4 / 64 / 83 / 43 / 6$ \\
$7.5 \mathrm{YR}$ & $4 / 83 / 43 / 6$ \\
\hline
\end{tabular}

\subsubsection{Yellow "Sarl"}

The selection shows close responses. Although 13 different colour samples were picked out of seven different pages, the dominating preferences are only from pages $2.5 \mathrm{Y}$ and $5 \mathrm{Y}$ of the Munsell Color System ( $p$-value: .0001, Appendix B).

The colour samples constituting the range for yellow "sarı" are (Appendix E, Fig. E.6):

\begin{tabular}{ll}
\hline Colour page & Colour sample \\
\hline $2.5 \mathrm{Y}$ & $8 / 16$ \\
$5 \mathrm{Y}$ & $8.5 / 14$ \\
\hline
\end{tabular}

\subsubsection{Green "Yeşil"}

Distributed over a total of 12 colour pages, 23 different colour samples were selected to be the best representatives of green "yeşil". Three colour pages were significant among the selected ones.

The colour samples constituting the range for green "yeşil" are ( $p$-value: .0001, Appendices B and E, Fig. E.7):

\begin{tabular}{ll}
\hline Colour page & Colour sample \\
\hline $7.5 \mathrm{GY}$ & $6 / 12$ \\
$10 \mathrm{GY}$ & $5 / 12$ \\
$2.5 \mathrm{GY}$ & $5 / 12$ \\
\hline
\end{tabular}

\subsubsection{Blue "Mavi"}

Responses were grouped under pages 10B, 2.5PB and $5 \mathrm{~PB}$ of the Munsell Color System. Participants picked up 22 different colour samples during the tests.

The colour samples constituting the range for blue "mavi" are ( $p$-value: .0001, Appendices B and E, Fig. E.8):

\begin{tabular}{ll}
\hline Colour page & Colour sample \\
\hline $10 \mathrm{~B}$ & $5 / 12$ \\
$2.5 \mathrm{~PB}$ & $5 / 12$ \\
$5 \mathrm{~PB}$ & $4 / 12$ \\
\hline
\end{tabular}

\subsection{Analysis of non-basic colour names}

\subsubsection{Eggplant purple "Patlican moru"}

Eggplant purple "patlican moru", which is a type of purple, shows a different distribution pattern when compared to the basic colour name purple "mor". $2.2 \%$ of the participants did not know the colour the name 
defines. Five colour pages were identified representing the colour term eggplant purple "patlican moru", whereas for the basic colour name purple "mor", only two pages were selected. A total of 22 different colour samples were chosen to represent eggplant purple "patlican moru".

The colour samples constituting the range for eggplant purple "patlican moru" are ( $p$-value: .0052, Appendices B and E, Fig. E.9):

\begin{tabular}{ll}
\hline Colour page & Colour sample \\
\hline $2.5 \mathrm{P}$ & $2 / 62 / 10$ \\
$5 \mathrm{P}$ & $2 / 42 / 8$ \\
$7.5 \mathrm{P}$ & $2 / 42 / 6$ \\
$10 \mathrm{P}$ & $2 / 42 / 6$ \\
$10 \mathrm{~PB}$ & $2 / 10$ \\
\hline
\end{tabular}

Pearson correlation coefficient shows a similarity between the colour choices for eggplant purple "patlican moru" and lilac "leylak" ( $p$-value: .001, Appendix C).

\subsubsection{Lilac "Leylak"}

Although responses for lilac "leylak" were distributed over a large number of colour pages and $37.6 \%$ of the participants did not know which colour the name represents, lilac "leylak" is one of the non-basic colour names that holds close colour choices. Only five colour samples are significant among the whole stimuli.

The colour samples constituting the range for lilac "leylak" are ( $p$-value: .0001, Appendices B and E, Fig. E.10):

\begin{tabular}{ll}
\hline Colour page & Colour sample \\
\hline $2.5 \mathrm{P}$ & $7 / 86 / 8$ \\
$5 \mathrm{P}$ & $7 / 86 / 85 / 10$ \\
\hline
\end{tabular}

The selection of colour samples for eggplant purple "patlican moru" and lilac "leylak" show similarities and moderate correlation has been identified ( $p$-value: .001, Appendix C). A correlation has also been identified between lilac "leylak" and violet "eflatun" ( $p$-value: .001, Appendix C).

\subsubsection{Violet "Eflatun"}

$21.1 \%$ of the participants did not give any response when the term was assigned. Ten different colour pages and 27 different colour samples from these colour pages were cited to express the perceived colour for violet "eflatun".

The colour samples constituting the range for violet "eflatun" are ( $p$-value: .0001, Appendices B and E, Fig. E.11):

\begin{tabular}{|c|c|}
\hline Colour page & Colour sample \\
\hline $2.5 \mathrm{P}$ & $7 / 8 \quad 6 / 8 \quad 5 / 104 / 12$ \\
\hline $5 \mathrm{P}$ & $7 / 8 \quad 6 / 8 \quad 5 / 10$ \\
\hline $7.5 \mathrm{P}$ & $7 / 8 \quad 6 / 10 \quad 5 / 104 / 12$ \\
\hline
\end{tabular}

Pearson correlation coefficient given in Appendix C shows a moderate relationship between the colour choices for lilac "leylak" and violet "eflatun" ( $p$-value: .001, Appendix C).

\subsubsection{Gypsy pink "Cingene pembesi"}

Nearly all of the participants, except $3.1 \%$, identified this non-basic colour name. Among eight colour pages, 17 colour samples were selected.

The colour samples constituting the range for gypsy pink "çingene pembesi" are ( $p$-value: .0001, Appendices B and E, Fig. E.12):

\begin{tabular}{ll}
\hline Colour page & Colour sample \\
\hline $2.5 \mathrm{RP}$ & $6 / 124 / 12$ \\
$5 \mathrm{RP}$ & $5 / 124 / 12$ \\
$7.5 \mathrm{RP}$ & $5 / 14$ \\
$10 \mathrm{RP}$ & $5 / 144 / 14$ \\
\hline
\end{tabular}

Pearson correlation coefficient shows a relationship between the colour choices for gypsy pink "çingene pembesi" and pink "pembe" ( $p$-value: .001, Appendix C). A similar relationship is also significant between gypsy pink "çingene pembesi" and rose "gül kurusu" ( $p$-value: .001, Appendix C).

\subsubsection{Rose "Gül kurusu"}

The selection of a colour sample to represent rose "gül kurusu" varied in great number: the participants noted 32 different colour samples. $17.1 \%$ of the respondents stated they could not visualise the colour term. Although 11 different colour pages were referred to, only two of them were statistically significant.

The colour samples constituting the range for rose "gül kurusu" are ( $p$-value: .0001, Appendices B and E, Fig. E.13):

\begin{tabular}{ll}
\hline Colour page & Colour sample \\
\hline $7.5 \mathrm{RP}$ & $4 / 123 / 10$ \\
$10 \mathrm{RP}$ & $5 / 123 / 102 / 8$ \\
\hline
\end{tabular}

Rose "gül kurusu" and gypsy pink "çingene pembesi" are two different colour terms, but they have a moderate degree of relationship with each other when their colour pages are considered ( $p$-value: .001, Appendix C). The 
colour pages of pink "pembe" and rose "gül kurusu" also show similarities during the identification process ( $p$-value: .001, Appendix C).

\subsubsection{Salmon "Yavruağzi"}

$24.8 \%$ of the participants could not show any colour sample to represent this colour term. Although 23 different colour samples from 14 different pages were selected, only four of them were statistically significant.

The colour samples constituting the range for salmon "yavruağzl" are (p-value: .0001, Appendices B and E, Fig. E.14):

\begin{tabular}{ll}
\hline Colour page & Colour sample \\
\hline $7.5 \mathrm{R}$ & $7 / 10$ \\
$10 \mathrm{R}$ & $8 / 67 / 10$ \\
$2.5 \mathrm{YR}$ & $8 / 6$ \\
\hline
\end{tabular}

Among the colour samples chosen for salmon "yavruağzı", colour samples $8 / 6$ are lighter colour samples when compared to $7 / 10$, the darker ones. Although main concentration for this non-basic colour name is on samples $8 / 6$, the darker $7 / 10$ are also significant among all other preferences. Thus, the perception of this colour term is either from a darker or a lighter stimulus.

\subsubsection{Bordeaux red "Bordo"}

Bordeaux red "bordo" is a non-basic colour name, which was almost equally selected from four different colour pages. The colour range for this term is composed of the $10 \mathrm{RP}, 2.5 \mathrm{R}, 5 \mathrm{R}$ and $10 \mathrm{R}$ colour pages of the Munsell Color System. Although 20 different colour samples were selected, only two of them $(2 / 8$ and $3 / 10$ ) of certain colour pages were significant.

The colour samples constituting the range for Bordeaux red "bordo" are ( $p$-value: .0001, Appendices B and E, Fig. E.15):

\begin{tabular}{ll}
\hline Colour page & Colour sample \\
\hline $10 \mathrm{RP}$ & $3 / 102 / 8$ \\
$2.5 \mathrm{R}$ & $3 / 102 / 8$ \\
$5 \mathrm{R}$ & $3 / 102 / 8$ \\
$7.5 \mathrm{R}$ & $3 / 122 / 8$ \\
\hline
\end{tabular}

\subsubsection{Scarlet "Klzll"}

Scarlet "k1zil" is a non-basic colour name that carries different colour percept. $22.7 \%$ of the participants could not identify the colour. Twenty-six different colour samples were specified to exemplify scarlet "kızll".
The colour samples constituting the range for scarlet "kızıl" are (p-value: .0001, Appendices B and E, Fig. E.16):

\begin{tabular}{ll}
\hline Colour page & Colour sample \\
\hline $7.5 \mathrm{R}$ & $5 / 164 / 163 / 103 / 122 / 8$ \\
$5 \mathrm{R}$ & $3 / 8 \quad 3 / 102 / 8$ \\
$10 \mathrm{R}$ & $4 / 123 / 10$ \\
\hline
\end{tabular}

The selection of colour samples for scarlet "kizll" and tile red "kiremit rengi" show similarities and moderate correlation has been identified ( $p$-value: .001, Appendix C).

\subsubsection{Blood red "Kan kırmizısl"}

Blood red "kan kirmizisı" is one of the colour names that unites the responses of the participants nearly into a single page. Colour page $7.5 \mathrm{R}$ is the dominant colour page among the selected seven pages. Only 14 different colour samples were preferred during the tests and two of these were statistically significant.

The colour samples constituting the range for blood red "kan kırmızısı" are (p-value: .0001, Appendices B and E, Fig. E.17):

\begin{tabular}{ll}
\hline Colour page & Colour sample \\
\hline $7.5 \mathrm{R}$ & $4 / 163 / 12$ \\
\hline
\end{tabular}

\subsubsection{Sour cherry "Vişne çürüğü"}

$11.2 \%$ of the participants could not give any response to this colour name. Eight colour pages were used in the selection of 20 different colour samples for sour cherry "vişne çürüğü".

The colour samples constituting the range for sour cherry "vișne çürüğü" are ( $p$-value: .0001, Appendices B and E, Fig. E.18):

\begin{tabular}{ll}
\hline Colour page & Colour sample \\
\hline $2.5 \mathrm{R}$ & $3 / 83 / 102 / 8$ \\
$5 \mathrm{R}$ & $3 / 102 / 8$ \\
$7.5 \mathrm{R}$ & $3 / 102 / 8$ \\
\hline
\end{tabular}

Colour choices for red "kırmız" show similarities with choices for sour cherry "vişne çürüğü" ( $p$-value: .001, Appendix C).

\subsubsection{Tile red "Kiremit rengi"}

Although most of the participants agreed that they knew the colour name, the number of colour samples 
picked was very high. A total of 28 colour samples were selected from eight different pages. When compared to other terms, there are many colour samples included in the range constructed for this non-basic colour name.

The colour samples constituting the range for tile red "kiremit rengi" are ( $p$-value: .0001, Appendices B and E, Fig. E.19):

\begin{tabular}{|c|c|}
\hline Colour page & Colour sample \\
\hline $7.5 \mathrm{R}$ & $5 / 124 / 8 \quad 4 / 104 / 123 / 83 / 10$ \\
\hline $10 \mathrm{R}$ & $5 / 85 / 105 / 14$ 4/8 4/10 4/12 3/8 3/10 \\
\hline $2.5 \mathrm{YR}$ & $4 / 10$ \\
\hline
\end{tabular}

Pearson correlation suggests a positive, but weak relationship between the colour selections for tile red "kiremit rengi" and scarlet "kizll" ( $p$-value: .001, Appendix C).

\subsubsection{Melon yellow "Kavuniçi"}

$5.6 \%$ of the participants could not show a sample for melon yellow "kavuniçi". Colour samples chosen for this name are very close in value and chroma. The samples chosen are all the same with samples chosen for orange "turuncu" with additions of samples 7/12 from pages $2.5 \mathrm{YR}$ and $5 \mathrm{YR}$.

The colour samples constituting the range for melon yellow "kavuniçi" are ( $p$-value: .0001, Appendices B and E, Fig. E.20):

\begin{tabular}{ll}
\hline Colour page & Colour sample \\
\hline $10 \mathrm{R}$ & $6 / 14$ \\
$2.5 \mathrm{YR}$ & $7 / 126 / 146 / 16$ \\
$5 \mathrm{YR}$ & $7 / 127 / 14$ \\
\hline
\end{tabular}

\subsubsection{Hazel "Ela"}

Known especially as an eye colour, it is one of the most problematic colour terms that carries difficulties in constructing a colour image in the minds of the participants. Nearly half of the participants, $48.1 \%$, could not identify the colour represented by this term. Most of the participants stated they knew the colour, but they could not map it on the colour scale.

The colour samples constituting the range for hazel "ela" are ( $p$-value: .0001, Appendices B and E, Fig. E.21):

\begin{tabular}{ll}
\hline Colour page & Colour sample \\
\hline $10 \mathrm{YR}$ & $6 / 66 / 86 / 105 / 64 / 8$ \\
$2.5 \mathrm{Y}$ & $5 / 64 / 44 / 6$ \\
$5 \mathrm{Y}$ & $6 / 85 / 45 / 65 / 8$ \\
\hline
\end{tabular}

\subsubsection{Beige "Bej"}

Nearly all colour samples having values between 9 and 7, and having chroma 1, 2 and 4 were considered to be the examples of beige "bej".

The colour samples constituting the range for beige "bej" are ( $p$-value: .0001, Appendices B and E, Fig. E.22):

\begin{tabular}{ll}
\hline Colour page & Colour sample \\
\hline $10 \mathrm{YR}$ & $9 / 19 / 29 / 48 / 18 / 28 / 4$ \\
$2.5 \mathrm{Y}$ & $9 / 29 / 48.5 / 28 / 47 / 4$ \\
\hline
\end{tabular}

Pearson correlation coefficients show that colour pages beige "bej" and cream "krem" ( $p$-value: .001, Appendix C), and beige "bej" and ivory "fildiși" ( $p$-value: .001, Appendix C) have moderate relationship.

\subsubsection{Canary yellow "Kanarya sartsı"}

$2.8 \%$ of the participants could not identify the colour that the term signifies.

The colour samples constituting the range for canary yellow "kanarya sarısı" are ( $p$-value: .0001, Appendices B and E, Fig. E.23):

\begin{tabular}{ll}
\hline Colour page & Colour sample \\
\hline $2.5 \mathrm{Y}$ & $8 / 16$ \\
$5 \mathrm{Y}$ & $8.5 / 128.5 / 14$ \\
\hline
\end{tabular}

\subsubsection{Cream "Krem"}

Only $.9 \%$ of the participants could not identify this colour term with a colour sample.

The colour samples constituting the range for cream "krem" are ( $p$-value: .0001, Appendices B and E, Fig. E.24):

\begin{tabular}{ll}
\hline Colour page & Colour sample \\
\hline $10 \mathrm{YR}$ & $9 / 4$ \\
$2.5 \mathrm{Y}$ & $9 / 29 / 4$ \\
$5 \mathrm{Y}$ & $9 / 29 / 4$ \\
\hline
\end{tabular}

Pearson correlation coefficients show that colour pages beige "bej" and cream "krem" show significant similarities ( $p$-value: .001, Appendix C).

\subsubsection{Lemon yellow "Limon sartsi"}

It is one of the colour terms that a great amount of agreement was achieved on certain colour samples. 
The colour samples constituting the range for lemon yellow "limon sarıs1" are ( $p$-value: .0001, Appendices B and E, Fig. E.25):

\begin{tabular}{ll}
\hline Colour page & Colour sample \\
\hline $5 \mathrm{Y}$ & $8.5 / 108.5 / 128.5 / 14$ \\
$7.5 \mathrm{Y}$ & $8.5 / 12$ \\
\hline
\end{tabular}

\subsubsection{Honey yellow "Bal rengi"}

Honey yellow "bal rengi" had great amount of responses in the $2.5 \mathrm{Y}$ page of the Munsell Color System. Adjacent colour samples (having same value and differ in chroma) $7 / 8,7 / 10$ and $7 / 12$ are statistically significant from this dominant colour page.

The colour samples constituting the range for honey yellow "bal rengi" are ( $p$-value: .0001, Appendices B and E, Fig. E.26):

\begin{tabular}{ll} 
Colour page & Colour sample \\
\hline $2.5 \mathrm{Y}$ & $7 / 87 / 107 / 128.5 / 68.5 / 88 / 106 / 10$ \\
\hline
\end{tabular}

\subsubsection{Ivory "Fildişi"}

Ivory "fildişi" had responses for colour samples having high value and low chroma. Like the colour preferences for beige "bej", nearly all colour samples having a value of 9 and chroma between 1 and 4 were considered as ivory "fildişi”" by most of the participants.

The colour samples constituting the range for ivory "fildiși" are (p-value: .0001, Appendices B and E, Fig. E.27):

\begin{tabular}{ll}
\hline Colour page & Colour sample \\
\hline $10 \mathrm{YR}$ & $9 / 19 / 2$ \\
$2.5 \mathrm{Y}$ & $9 / 29 / 4$ \\
$5 \mathrm{Y}$ & $9 / 29 / 48.5 / 2$ \\
\hline
\end{tabular}

Colour pages for ivory "fildişi," and beige "bej" were the same except the colour page 5Y, which was referred to for ivory. Pearson correlation coefficient also supports this similarity ( $p$-value: .001, Appendix C).

\subsubsection{Olive green "Zeytin yeşili"}

The total number of selected colour samples for this colour term was 35 . Although this range might seem to be large, there were still recurrently selected pages and colour samples.
The colour samples constituting the range for olive green "zeytin yeşili" are ( $p$-value: .0001, Appendices B and E, Fig. E.28):

\begin{tabular}{|c|c|}
\hline Colour page & Colour sample \\
\hline $7.5 \mathrm{Y}$ & $6 / 8 \quad 5 / 6$ \\
\hline $10 \mathrm{Y}$ & $6 / 8 \quad 5 / 6$ \\
\hline $2.5 \mathrm{GY}$ & $6 / 105 / 65 / 84 / 6$ \\
\hline $5 \mathrm{GY}$ & $6 / 8 \quad 4 / 4 \quad 4 / 8 \quad 3 / 6$ \\
\hline
\end{tabular}

Pearson correlation coefficients show that colour pages olive green "zeytin yeșili" and pistachio green "fistık yeşili" ( $p$-value: .001, Appendix C), and olive green "zeytin yeşili" and unripe almond green "çağla yeşili" ( $p$-value: .001, Appendix C) have moderate relationship.

\subsubsection{Pistachio green "Fistık yeşili"}

The colour samples constituting the range for pistachio green "fistık yeşili" are ( $p$-value: .0001, Appendices B and E, Fig. E.29):

\begin{tabular}{ll}
\hline Colour page & Colour sample \\
\hline $2.5 \mathrm{GY}$ & $8 / 127 / 107 / 12$ \\
$5 \mathrm{GY}$ & $7 / 12$ \\
$7.5 \mathrm{GY}$ & $6 / 12$ \\
\hline
\end{tabular}

Pearson correlation coefficients show that colour pages olive green "zeytin yeşili" and pistachio green "fistık yeşili" ( $p$-value: .001, Appendix C), and pistachio green "fıstık yeşili" and unripe almond green "çağla yeșili" ( $p$-value: .001, Appendix $C$ ) have moderate relationship.

The colour page preferences for the three non-basic colour names, from the green region of the spectrum show similarities, but the degree of relationship is moderate.

\subsubsection{Unripe almond green "çağla yeşili"}

Thirty-four different colour samples were considered to be representatives of this colour name. Recurring samples from different pages were grouped to construct the general colour range for unripe almond green "çağla yeşili”".

The colour samples constituting the range for unripe almond green "çağla yeşili" are ( $p$-value: .0019, Appendices B and E, Fig. E.30):

\begin{tabular}{ll} 
Colour page & Colour sample \\
\hline $2.5 \mathrm{GY}$ & $7 / 67 / 8$ \\
$5 \mathrm{GY}$ & $7 / 67 / 126 / 105 / 10$
\end{tabular}




\begin{tabular}{ll}
$7.5 \mathrm{GY}$ & $5 / 65 / 8$ \\
$10 \mathrm{GY}$ & $7 / 66 / 66 / 105 / 6$ \\
\hline
\end{tabular}

Olive green "zeytin yeşili" and unripe almond green "çağla yeşili" have moderate relationship ( $p$-value: .001, Appendix C).

\subsubsection{Navy blue "Lacivert"}

This non-basic colour name is known by $98.8 \%$ of the respondents. The colour range exemplified for navy blue "lacivert" contains very close colour samples having same values but different chroma. Two colour pages $5 \mathrm{~PB}$ and $7.5 \mathrm{~PB}$ were recurrently referred to during the tests.

The colour samples constituting the range for navy blue "lacivert" are ( $p$-value: .0001, Appendices B and E, Fig. E.31):

\begin{tabular}{ll}
\hline Colour page & Colour sample \\
\hline $5 \mathrm{~PB}$ & $2 / 42 / 62 / 8$ \\
$7.5 \mathrm{~PB}$ & $2 / 42 / 62 / 10$ \\
\hline
\end{tabular}

Colour choices for navy blue "lacivert" show similarities with choices for night blue "gece mavisi" (p-value: .001, Appendix C).

\subsubsection{Night blue "Gece mavisi"}

The colour samples constituting the range for night blue "gece mavisi" are (p-value: .0001, Appendices B and E, Fig. E.32):

\begin{tabular}{ll}
\hline Colour page & Colour sample \\
\hline $5 \mathrm{~PB}$ & $2 / 83 / 10$ \\
$7.5 \mathrm{~PB}$ & $2 / 103 / 12$ \\
\hline
\end{tabular}

Similar colour choices were made for night blue "gece mavisi" and navy blue "lacivert". Pearson correlation coefficient also supports this similarity ( $p$-value: .001, Appendix C).

\section{Discussion}

Some general conclusions can be drawn from the data collected for basic and non-basic colour names. These are:

1. For all the basic colour names, the chosen colour samples were the most saturated samples of the referred pages. Although the value and colour pages of the selected samples differed according to the assigned colour name, in all cases the most saturated colour samples were chosen by the participants to be the best representatives of each basic colour name.

2. The representative colour ranges for each basic colour name had colour samples very close to each other from value and chroma point of view. However, the range for pink "pembe" held two different types of colour stimuli that can be distinguished immediately. Colour samples $8 / 6$ from colour pages $2.5,5$ and 7.5RP are lighter colours than the colour samples $6 / 12$ from colour pages 2.5 and 5RP. Thus, two different images for pink "pembe" exist for Turkish people, either a light colour or a dark one.

3. Responses for green "yeşil" were concentrated on the GY (green-yellow) pages of the Munsell Color System, while the system has its own page for green $(\mathrm{G})$.

4. The visualised or selected blue "mavi" were mostly samples placed in the PB (purple-blue) pages of the Munsell Color System. Only one blue page of the system, the 10B, was used to indicate this colour.

5. Colour ranges for basic colour names had colour samples in close proximity for most of the time. There was not much variation in the values and chroma of the selected colour samples and they were even the same for different pages belonging to the same colour (e.g., colour range for blue "mavi" holds samples $5 / 12$ of $10 \mathrm{~B}$ page, $5 / 12$ of $2.5 \mathrm{~PB}$ and $4 / 12$ of $5 \mathrm{~PB}$ page).

6. Except for the basic colour names yellow "sar1" and brown "kahverengi", the city of residence has an effect on all of the remaining basic colour names ( $p$-value between .00011 and .02107, Appendix D). Gender does not have an effect on colour naming for basic colour names ( $p$-value between .12973 and .74278, Appendix D). Age ( $p$-value between .00070 and .00415 , Appendix D) and occupation ( $p$-value between .00002 and .01729 , Appendix D) have an effect on the perception of the basic colour names of pink "pembe", red "kırmızı" and orange "turuncu". Despite the differences depending on these independent variables, for most of the basic colour names differences among perceiving colours were not so distinct. It could be said that Turkish-speaking people have enough agreement and common understanding in determining the range for basic colour names.

7. Non-basic colour names are used to make finer adjustments, descriptions and definitions, using surface characteristics of coloured objects. A basic colour name, on the other hand, represents a general range of colour than a specific one. For most of the non-basic colour names, the ranges assembled by the choices of participants included more colour samples having different values and chroma when compared to basic colour names. 
8. Lilac "leylak", blood red "kan kırmızısı", lemon yellow "limon sarısı", canary yellow "kanarya sarısı", night blue "gece mavisi" and navy blue "lacivert" are the non-basic colour names that have a smaller range of colour samples as a representative group. On the other hand, violet "eflatun", tile red "kiremit rengi", hazel "ela", olive green "zeytin yeşili", pistachio green "fıstık yeşili" and unripe almond green "çağla yeşili" are the colour terms that have wider distribution of colour samples on different colour pages.

9. Colour samples selected for yellow "sar1" and canary yellow "kanarya sarısı" are very close to each other. These two colour terms represent nearly the same colour range although they are different from each other linguistically.

10. Orange "turuncu" and melon yellow "kavuniçi" also hold similar and sometimes same colour samples. Although one of them is a basic colour name and the other is a non-basic colour name, the images of the colour in the minds of Turkish people are almost the same. This relationship between orange "turuncu" and melon yellow "kavuniçi" is interesting when the surface colours of the referred objects are taken into account. When the colour term honey yellow "bal rengi" was assigned to the participants of the study, most of them asked the question "what type of honey should we consider?" However none of the participants thought about different types of melon while selecting a colour sample for melon yellow. Although the actual surface colours of two fruits "turunç" (a type of orange) and "kavun" (melon) are different from each other, responses showed that these colour terms are perceived identical.

11. Blood red "kan kırmızısı" is the only non-basic colour name that has a great amount of agreement both on its colour page and the chosen colour samples. When the data for blood red "kan kırmızısı" and red "kırmızı" are compared, blood red was defined with two samples, while red was defined with four colour samples. This occurrence was against the general trend where non-basic colour names are defined with more colour samples than basic colour names.

12. Violet "eflatun" and lilac "leylak" are two non-basic colour names that have similar colour ranges ( $p$-value .001, Appendix C). For violet "eflatun", a total of twenty-seven colour samples were selected out of 10 colour pages. For lilac "leylak", 26 colour samples were selected from 11 different pages. The difference is in the variety of colour samples in the range constructed for each colour term. Although violet "eflatun" is known by $78.9 \%$ of the participants, its colour range has more colour samples than the range for lilac "leylak", known by $62.4 \%$ of the participants.

13. Lilac, violet and rose as flowers have many tints and shades. This might have had an effect on the selection of colour samples with these names. Although the participants were familiar with these colour names, it was difficult for them to come to a consensus on a few colour samples representing these terms.

14. Beige "bej", cream "krem" and ivory "fildiși" are three different colour terms presumably carrying different colour percepts. However, not only the colour pages, but also some of the colour samples picked up, were the same for these non-basic colour names. Davaz [6] includes ivory "fildişi" in the white, cream "krem" in the yellow and beige "bej" in the brown section of colour terminology. From the results of this study, it is worth thinking whether the colour represented by these three different colour terms might actually be the same colour.

15. Navy blue "lacivert" is a non-basic colour name that was picked up as quickly as a basic colour name by the participants. It is a potential word to become a basic colour name, as in the case of "light blue" being a basic colour name for Russians [7]. The colour range exemplified for navy blue "lacivert" contains very close colour samples from two colour pages, 5 and 7.5PB. Selected colour samples from these pages also have same values.

16. The participants did not worry about precisely distinguishing the colour samples for each assigned colour term. Some participants used the same colour sample from the same colour page to represent two different non-basic colour names (e.g., the cases for Bordeaux red "bordo" and sour cherry "vişne çürüğü" or for cream "krem" and ivory "fildişiı"). This might be due to close colour values of these pairs, which make finer adjustments difficult. On the other hand, it might be the case that these colour pairs could be the same for Turkish people. Thus, Turkish people, sometimes and for some specific colours, might have a tendency to use a single term.

17. Among all the non-basic colour names, the ones belonging to the green region of the spectrum were problematical. Total selected sample number exceeded 35 , which means there is a great variation in perception and visualisation. Participants concentrated on a smaller number of colour samples for pistachio green "fıstık yeșili" when compared to other colour terms from the green region of the colour spectrum. Unripe almond green "çağla yeşili" and olive green "zeytin yeșili" are represented by a number of different colour samples. 
18. Gypsy pink "çingene pembesi" had an image representation nearly for all of the participants, although there is no object to look at or to refer to, for the actual colour carried by this word.

19. It can be concluded that the risk of understanding different colours is high when a non-basic colour name is vocalised. The image of a colour in one's mind may be totally different from someone else's while using these colour terms in communication.

20. In this study, men and women were found equally successful in discriminating colour stimulus.

21. Effects of city of residence, age, gender and occupation on colour naming for non-basic colour terms were investigated in this study (Appendix D). All these factors have an effect on colour naming and perception for non-basic colour names, but their influences vary according to the specific colour stimulus.

22. Gender has an effect on Bordeaux red "bordo", gypsy pink "çingene pembesi", melon yellow "kavuniçi", beige "bej", honey yellow "bal rengi" and navy blue "lacivert", but not on other colours ( $p$ values between .00001 and .04408 , Appendix D).

23. City of residence has an effect on eggplant purple "patlican moru", violet "eflatun", gypsy pink "çingene pembesi", salmon "yavruağzı", tile red "kiremit rengi", melon yellow "kavuniçi", cream "krem", pistachio green "fıstık yeşili", unripe almond green "çağla yeșili" and night blue "gece mavisi", but not on other colours ( $p$-values between .00001 and .03932, Appendix D).

24. Age has an effect on eggplant purple "patlican moru", violet "eflatun", rose "gül kurusu", salmon "yavruağzı", blood red "kan kırmızısı", cream "krem", honey yellow "bal rengi", ivory "fildişi”,, olive green "zeytin yeşili", unripe almond green "çağla yeșili" and night blue "gece mavisi", but not on other colours ( $p$-values between .00019 and .04449 , Appendix D).

25. Occupation (field of study) has an effect on rose "gül kurusu", salmon "yavruağzı", beige "bej”, canary yellow "kanarya sarısı", cream "krem", honey yellow "bal rengi" and night blue "gece mavisi", but not on other colours ( $p$-values between .00055 and .04768, Appendix D).

\section{Research notes}

Observations, thoughts and records collected during the experimental research might be of interest for researchers in the field. This section is devoted to research notes collected with no scientific intent as unplanned data. They consist partly of participants' attitudes during the experiments and might guide other investigations in the future.

1. Turquoise "türkuvaz" is known as a colour name, but colour samples representing this term could not be identified by most of the participants. Although turquoise "türkuvaz" is also known as "Türk mavisi" (Turkish blue), the colour name "Türk mavisi" was also eliminated by all the subjects. The same situation was also the case for "bayrak kirmizısı" ("flag red" from the Turkish flag) and “Türk kırmızısı" (Turkish red).

2. Four different colour names were found that described ice "buz": ice blue "buz mavisi", ice green "buz yeșili", ice pink "buz pembesi" and ice white "buz beyazi". In order to prevent directing the participants to a specific colour, the name was given as "buz rengi" (ice colour) without any colour specification. Colour preferences for "buz rengi" (ice colour) were from PB (purple-blue) and B (blue) pages. Nobody responded to the colour with a pink or a green sample.

3. Many of the participants were surprised to realise the huge range of colours.

4. Several participants complained that the Munsell Color System did not carry a colour sample for gypsy pink "çingene pembesi". Most of the participants searched for a brighter and more vivid pink than is available in the Munsell Color Book.

5. Participants, most of the time, were dissatisfied with the yellow range offered by Munsell Color System. They stated that the system did not include the yellow they had in mind. They referred to the row of samples having value of 8.5 most of the time.

6. Some of the non-basic colour names frequently used in daily life were found to be difficult to identify when asked to pick up the colour sample representing that colour. Participants sometimes asked questions like "which honey's colour?" for honey yellow "bal rengi" or "what colour of rose should we think?" to respond to rose "gül kurusu".

7. Scarlet "kizıl" was related with hair colour in all the cities investigated, except in Edirne. None of the participants in Edirne pronounced the concept of hair. When asked, "what colour do you think scarlet "kızil" is?", most of the participants described a kind of red and referred to other colour names as flame red "alev kırmızısı", fire red "ateş kırmızısı" in order to exemplify the colour they had in mind.

8. Some of the participants were selected from professions dealing with colour to investigate their approach to colour. Identification processes of these participants showed some facts about how industrialisation affects colour perception of people. People using colour as a tool in their work (wool dyers, carpet weavers, painters, embroiders, etc.) 
naturally use colour details. When they are in need of any colour, they refer to the codes, numbers given to the coloured material. They never use a specific colour name to refer to the colour they are looking for. For example, no colour names exist for the twines of needle workers. Instead of asking one to give the rose "gül kurusu" twine, they would only pronounce the code attached to the material by the related industry.

9. Workers of certain industries (especially wool dyers and carpet weavers) are accustomed to see, perceive and use colours in the way the colours are presented to them. For example, when individually interviewed, workers from dyeing departments of Sümer Hall, a large-size carpet corporation, only responded to the colours they were using at work. When they were asked to show a colour, they responded that the colour they use for the mentioned colour term did not exist in the Munsell Color System. These people are used to see and name colours in the way they are offered to them in the relevant industry.

10. After completing the tests, most of the participants asked whether or not they have chosen the true colour samples for the assigned terms and if we could show them the colour samples for colour names they could not identify. It might be argued that people believe in the existence of "true reds", "true purples" and the like.

\section{Conclusion}

The concept of colour recalls different ideas for each individual. To understand and appreciate different aspects of colour, one must experience at least basic concepts of colour from different disciplines. On the scientific side, physics of light, biology of the nervous system, complexity of the mind and colour use of living organisms to adapt themselves to their natural environment are within the field of colour studies. In the humanities, the history of colour in art, role of culture and language in colour concepts, principles of colour for a painter and the like are all different topics of colour to be experienced. Whatever the case, all our concepts of colour are expressed in language. Thus, the perception of colour is in the mind of the observer and communicated with others using necessary colour terms in language.

This paper presents an experimental research that has been done to identify colour terms in Turkish and to investigate their appearance in the minds of native Turkish speakers. The main purpose of this study is to identify colour samples reflecting the perception of basic and commonly known non-basic colour terms in
Turkish language. In order to have a representative participant group of Turkish people, native inhabitants of six different cities among different regions of the country were included in the study. It is important to note that findings of this study should be evaluated by taking the participant group into consideration.

Colour ranges, for most of the basic colour names, include very close colour samples. Most of the samples selected by participants have equal values or chroma. On the other hand, results obtained for most of the nonbasic colour names, show differences between the selected colour samples. It can be concluded that, when a basic colour name is vocalised, the visualised or portrayed colour in the minds of Turkish speaking people is approximately the same. Moreover, data obtained from different regions of Turkey show similar behaviour.

Age, gender, occupation and city of residence have an effect on perception of colour, but it is difficult to generalise the influence of these variables on colour, especially on the non-basic colour names. The significant effect of gender was observed in only six of the colour terms investigated (Appendix D). Similarly, the effect of using colour in occupation was significant on colour naming for only 10 colour terms out of a total of 32 (Appendix D). The significant effect of age was observed in 14 and the significant effect of city was observed in 16 of the cases investigated (Appendix D).

It is worth mentioning that language and perception work separately. Although cultural relativists claim that colour words rule the perception, some of the observed cases in this study do not favour this hypothesis. From the beginning of the project, and especially in the procedures of elimination, it was discovered that although participants said they knew the colour term, they could not show or choose a colour sample to represent that term. Colour names hazel "ela" and lilac "leylak" are examples for this situation. Ninety-two per cent of the participants stated they knew the term hazel "ela" and $86 \%$ of the participants stated they knew the term lilac "leylak". However, $48 \%$ of the participants could not pick up a colour sample for hazel "ela" and $38 \%$ could not pick up a sample for lilac "leylak", stating that they could not visualise the colour of the term. It is worth re-thinking on the hypothesis of the relativists before accepting that language determines perception.

The number of artificially created "colours" can be huge. The highest number encountered by the authors is no less than 8.6 billion, claimed by Panasonic in a very recent advertisement for their VIERA range of Plasma Televisions. To quote Panasonic "An equivalent of 8.6 billion on-screen colours (over 5 billion more than previously achieved) produce images that have to be seen to be believed" [8]. In this study, by contrast, a total of just 32 colour names - as commonly used in everyday 
Turkish language - shows how small a sample is sufficient in communications with colour. Words help us enrich, modify, execute, and above all communicate the language of colour. However, other than music and body language, colour presents to be the only kind of expression that does not require words.

\section{Acknowledgments}

The authors wish to thank Dr. Kağan Olguntürk, Department of Communication and Design, Bilkent University, Ankara for photographing the colour samples for this publication.

\section{Appendix A}

The final list of colour names used in the experiment:

Basic colour names:
1. Purple "mor"
2. Pink "pembe"
3. Red "kırmızı"
4. Orange "turuncu"
5. Brown "kahverengi"
6. Yellow "sarı"
7. Green "yeşil"
8. Blue "mavi"

\section{Non-basic colour names:}

1. Eggplant purple "patlican moru"

2. Lilac "leylak"

3. Violet "eflatun"

4. Gypsy pink "çingene pembesi"

5. Rose "gül kurusu"

6. Salmon "yavruağzi"

7. Bordeaux red "bordo"

8. Scarlet "kizil"

9. Blood red "kan kırmızısı"

10. Sour cherry "vişne çürüğü"

11. Tile red "kiremit rengi"

12. Melon yellow "kavuniçi",

13. Hazel "ela"

14. Beige "bej"

15. Canary yellow "kanarya sarısı"

16. Cream "krem"

17. Lemon yellow "limon sarisı"

18. Honey yellow "bal rengi"

19. Ivory "fildiși"

20. Olive green "zeytin yeșili"

21. Pistachio green "fistik yeşili"

22. Unripe almond green "çağla yeșili"

23. Navy blue "lacivert"

24. Night blue "gece mavisi"

\section{Appendix B}

Chi-square tests of colour pages and colour samples of the investigated colour names:

\begin{tabular}{|c|c|c|}
\hline & Colour name & $p$-value \\
\hline \multirow{8}{*}{$\begin{array}{l}\text { Basic colour } \\
\text { names }\end{array}$} & Purple "Mor" & .0001 \\
\hline & Pink "Pembe" & .0001 \\
\hline & Red “Kırmızı” & .0001 \\
\hline & Orange "Turuncu" & .0001 \\
\hline & Brown "Kahverengi" & .0001 \\
\hline & Yellow "Sarı" & .0001 \\
\hline & Green "Yeşil" & .0001 \\
\hline & Blue "Mavi" & .0001 \\
\hline \multirow[t]{24}{*}{$\begin{array}{l}\text { Non-basic } \\
\text { colour names }\end{array}$} & $\begin{array}{l}\text { Eggplant purple "Patlican } \\
\text { moru" }\end{array}$ & .0052 \\
\hline & Lilac "Leylak" & .0001 \\
\hline & Violet "Eflatun" & .0001 \\
\hline & $\begin{array}{l}\text { Gypsy pink "çingene } \\
\text { pembesi" }\end{array}$ & .0001 \\
\hline & Rose "Gül kurusu” & .0001 \\
\hline & Salmon "Yavruağzı" & .0001 \\
\hline & Bordeaux red "Bordo" & .0001 \\
\hline & Scarlet "Kizil”" & .0001 \\
\hline & Blood red "Kan kırmızısı" & .0001 \\
\hline & $\begin{array}{l}\text { Sour cherry "Vişne } \\
\text { çürügüü" }\end{array}$ & .0001 \\
\hline & Tile red "Kiremit rengi" & .0001 \\
\hline & Melon yellow "Kavuniçi” & .0001 \\
\hline & Hazel "Ela" & .0001 \\
\hline & Beige "Bej" & .0001 \\
\hline & $\begin{array}{l}\text { Canary yellow "Kanarya } \\
\text { sarıs1" }\end{array}$ & .0001 \\
\hline & Cream "Krem" & .0001 \\
\hline & $\begin{array}{l}\text { Lemon yellow "Limon } \\
\text { sarısı" }\end{array}$ & .0001 \\
\hline & Honey yellow "Bal rengi" & .0001 \\
\hline & Ivory “Fildişi”" & .0001 \\
\hline & Olive green "Zeytin yeșili" & .0001 \\
\hline & $\begin{array}{l}\text { Pistachio green "Fistık } \\
\text { yeşili" }\end{array}$ & .0001 \\
\hline & $\begin{array}{l}\text { Unripe almond green } \\
\text { "çağla yeșili"" }\end{array}$ & .0019 \\
\hline & Navy blue "Lacivert" & .0001 \\
\hline & Night blue "Gece mavisi" & .0001 \\
\hline
\end{tabular}




\section{Appendix C}

Pearson correlation coefficients investigating the degree of relationship between two different colour names:

Colour pairs p p-value

Lilac-Eggplant purple

"Leylak-Patlican moru"

Lilac-Violet

"Leylak-Eflatun"

Gypsy pink-Pink

"Çingene pembesi-Pembe"

Gypsy pink-Rose

"Çingene pembesi-Gül kurusu"

Pink-Rose

"Pembe-Gül kurusu"
.001

Red-Sour cherry

"Kırmız1-Vişne çürüğü"

Scarlet-Tile red

"Kızıl-Kiremit rengi"

Beige-Cream

"Bej-Krem"

Beige-Ivory

"Bej-Fildişi"

Olive green-Pistachio green

"Zeytin yeșili-Fıstık yeșili"

$.001 \quad$ Olive green-Unripe almond green

"Zeytin yeşili-Çağla yeşili"

$.001 \quad$ Pistachio green-Unripe almond green

"Fıstık yeșili-çağla yeșili"

$.001 \quad$ Navy blue-Night blue

"Lacivert-Gece mavisi"
.001

.001

.001

.001

.001

.001

.001

.001

\section{Appendix D}

Chi-square tests applied to the collected data to investigate significance of gender, age, city of residence and use of colour in occupation:

\begin{tabular}{|c|c|c|c|c|}
\hline Colours & $\begin{array}{l}\text { City } \\
p \text {-value }\end{array}$ & $\begin{array}{l}\text { Age } \\
p \text {-value }\end{array}$ & $\begin{array}{l}\text { Gender } \\
p \text {-value }\end{array}$ & $\begin{array}{l}\text { Occupation } \\
p \text {-value }\end{array}$ \\
\hline Purple "Mor" & .00043 & .66214 & .30065 & .21963 \\
\hline Pink "Pembe" & .01027 & .00070 & .51068 & .01729 \\
\hline Red “Kırmızı” & .00241 & .00415 & .69208 & .00002 \\
\hline Orange "Turuncu" & .00021 & .00125 & .31810 & .00081 \\
\hline Brown "Kahverengi" & .05986 & .16203 & .12973 & .37571 \\
\hline Yellow "Sarı" & .56658 & .12704 & .30472 & .18708 \\
\hline Green "Yeşil" & .00011 & .41582 & .74278 & .21300 \\
\hline Blue "Mavi", & .02107 & .21818 & .28789 & .39356 \\
\hline Eggplant purple "Patlican moru" & .00015 & .02915 & .15459 & .11798 \\
\hline Lilac "Leylak" & .94370 & .41316 & .32104 & .35210 \\
\hline Violet "Eflatun" & .00019 & .02052 & .05796 & .18883 \\
\hline Gypsy pink "Çingene pembesi" & .00091 & .88347 & .00001 & .18159 \\
\hline Rose "Gül kurusu", & .05649 & .02679 & .06711 & .01309 \\
\hline Salmon "Yavruağzı" & .00051 & .01229 & .16659 & .04136 \\
\hline Bordeaux red "Bordo" & .31401 & .73574 & .00102 & .71476 \\
\hline Scarlet "Kız1l" & .18776 & .38425 & .11317 & .24524 \\
\hline Blood red "Kan kırmızısı" & .65152 & .01802 & .93254 & .15048 \\
\hline Sour cherry "Vişne çürüğü" & .26017 & .78111 & .12211 & .12525 \\
\hline Tile red "Kiremit rengi"" & .01152 & .80152 & .13167 & .67285 \\
\hline Melon yellow "Kavuniçi", & .02283 & .13993 & .04408 & .06072 \\
\hline Hazel "Ela" & .44442 & .15952 & .43200 & .53984 \\
\hline Beige "Bej" & .12439 & .46838 & .01768 & .04768 \\
\hline Canary yellow "Kanarya sarısı" & .52506 & .16064 & .25110 & .01734 \\
\hline Cream "Krem" & .00013 & .04449 & .16589 & .00055 \\
\hline Lemon yellow "Limon sarısı" & .71002 & .24274 & .23052 & .11131 \\
\hline Honey yellow "Bal rengi" & .07818 & .01423 & .00011 & .04586 \\
\hline Ivory "Fildiși", & .14276 & .00019 & .16626 & .12205 \\
\hline Olive green "Zeytin yeșili" & .13758 & .03327 & .64335 & .40524 \\
\hline Pistachio green "Fıstık yeşili" & .00001 & .06485 & .40992 & .08389 \\
\hline
\end{tabular}


Unripe almond green "Çağla yeșili"

Navy blue "Lacivert"

.03932

.00280

.96655

.35303

Night blue "Gece mavisi"

.07892

.49266

.00112

.29879

.01312

.00140

.26483

.03712

\section{Appendix E}

Colour samples constituting the range for different colour names.

See Figs. E1-E32.
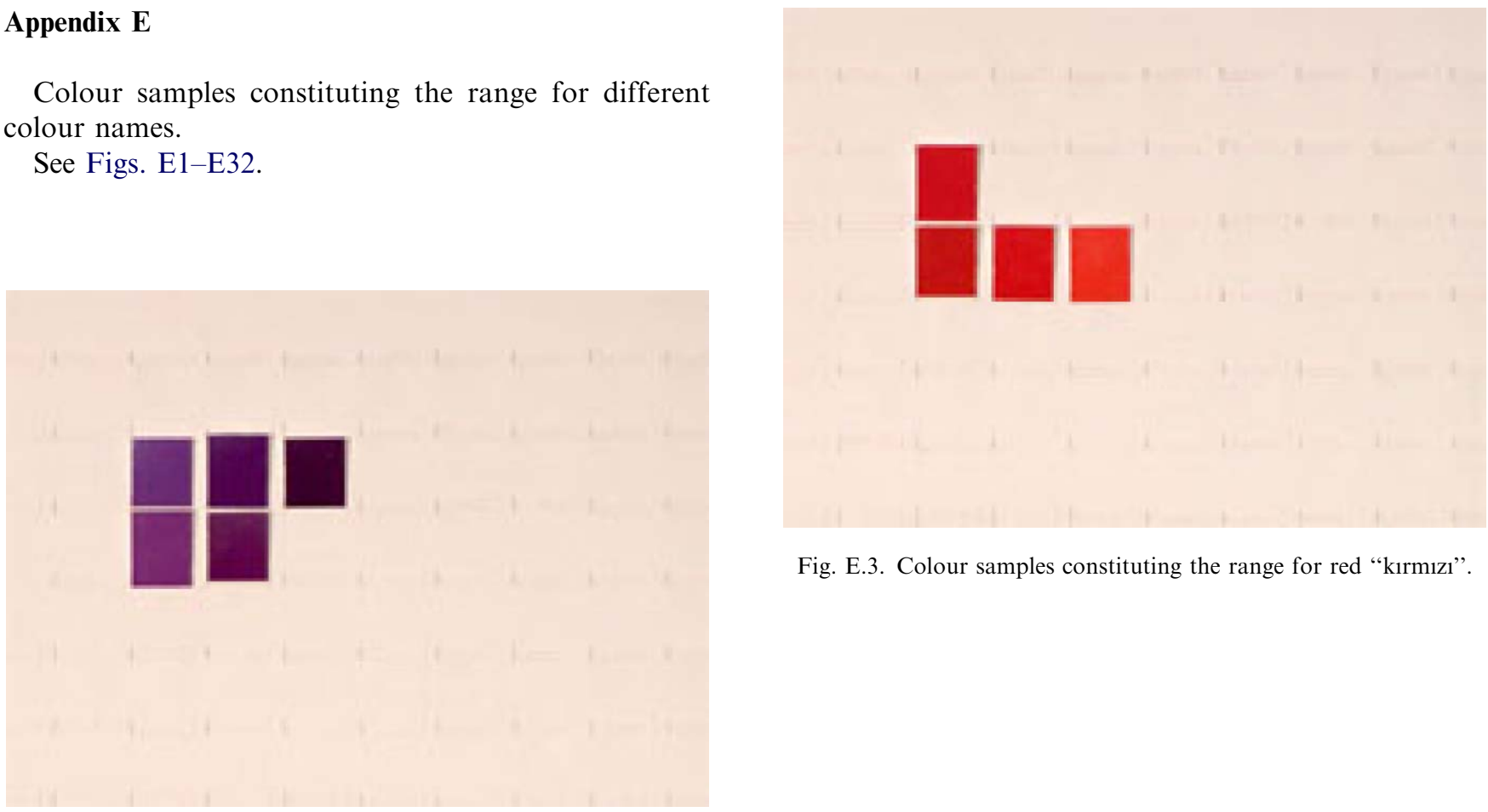

Fig. E.3. Colour samples constituting the range for red "kırmızı".

Fig. E.1. Colour samples constituting the range for purple "mor".
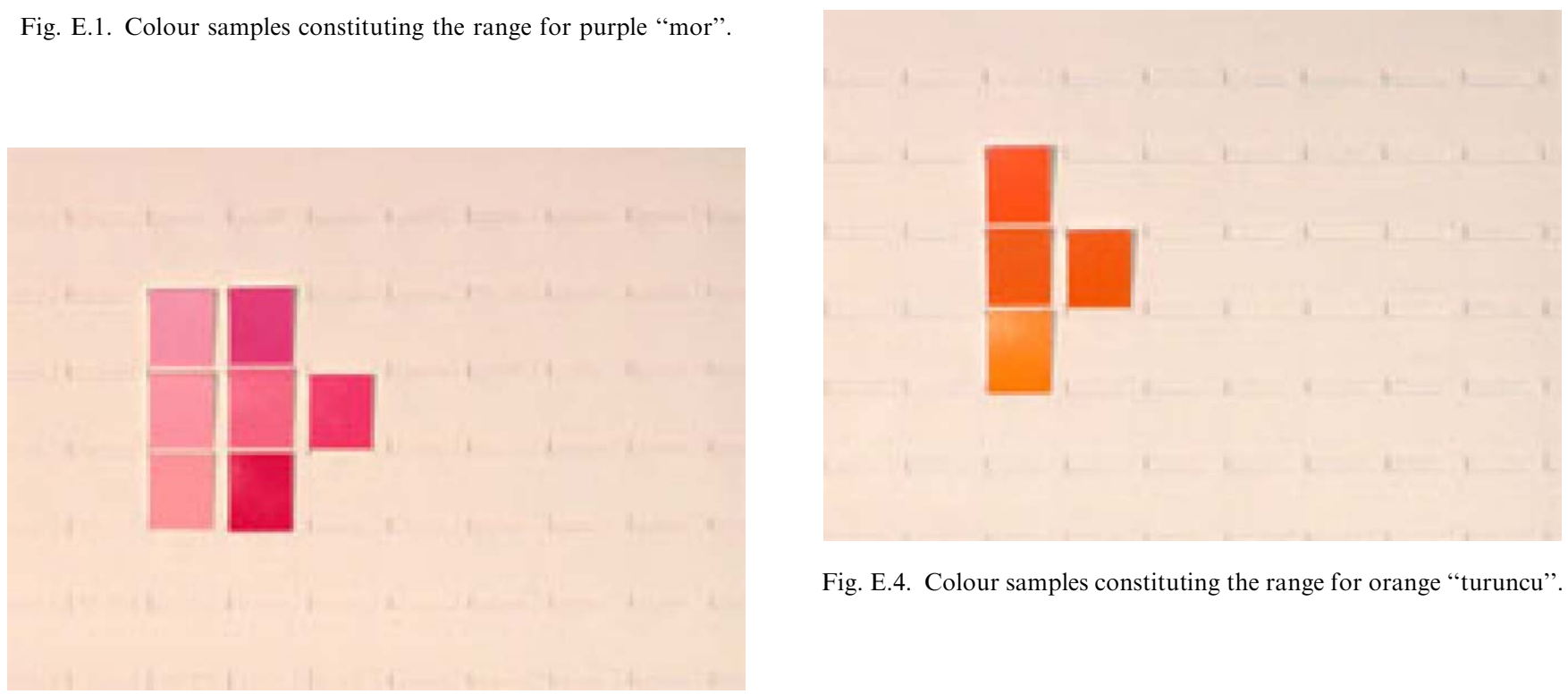

Fig. E.4. Colour samples constituting the range for orange "turuncu",

Fig. E.2. Colour samples constituting the range for pink "pembe". 


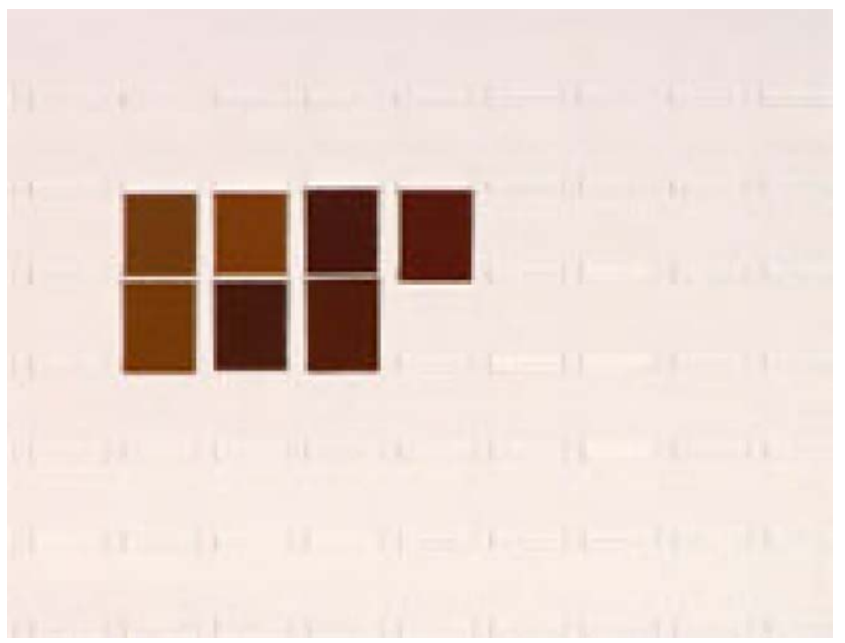

Fig. E.5. Colour samples constituting the range for brown "kahverengi".

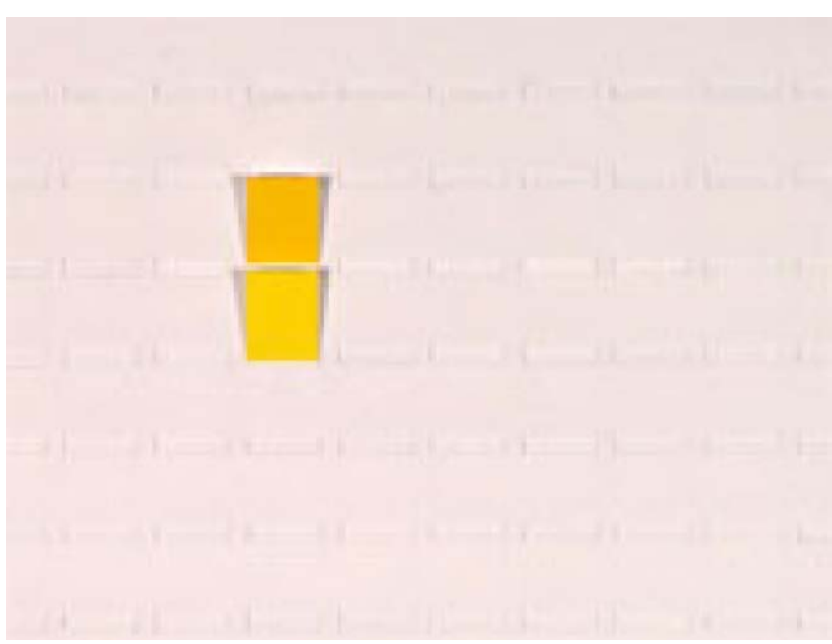

Fig. E.6. Colour samples constituting the range for yellow "sar1".

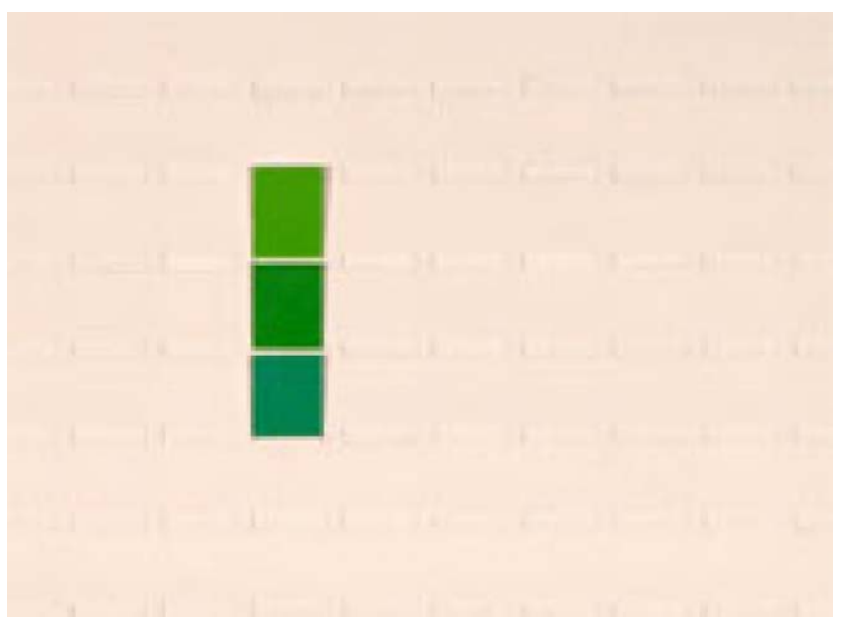

Fig. E.7. Colour samples constituting the range for green "yeșil".

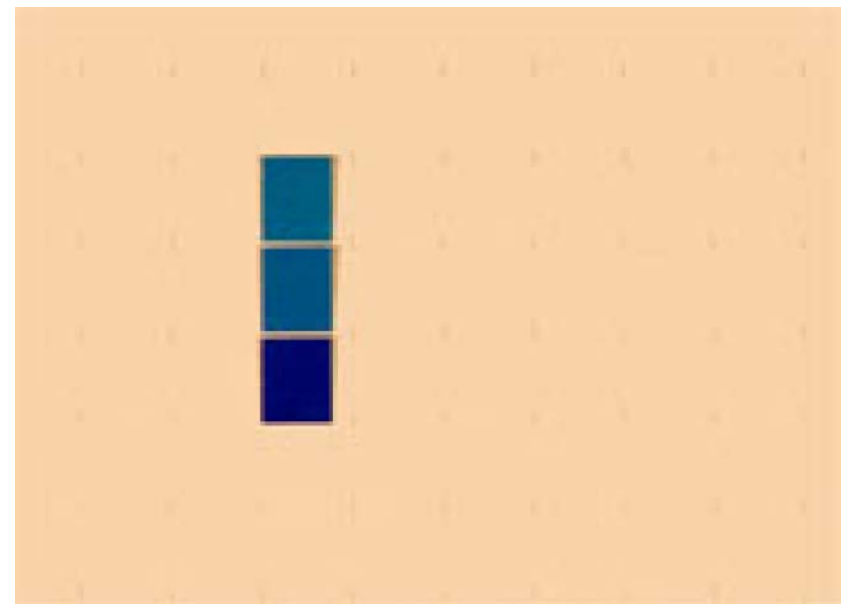

Fig. E.8. Colour samples constituting the range for blue "mavi".

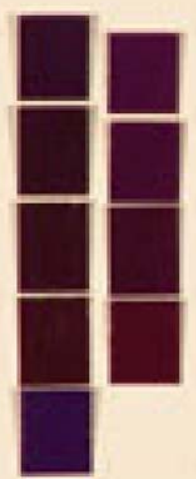

Fig. E.9. Colour samples constituting the range for eggplant purple "patlican moru".

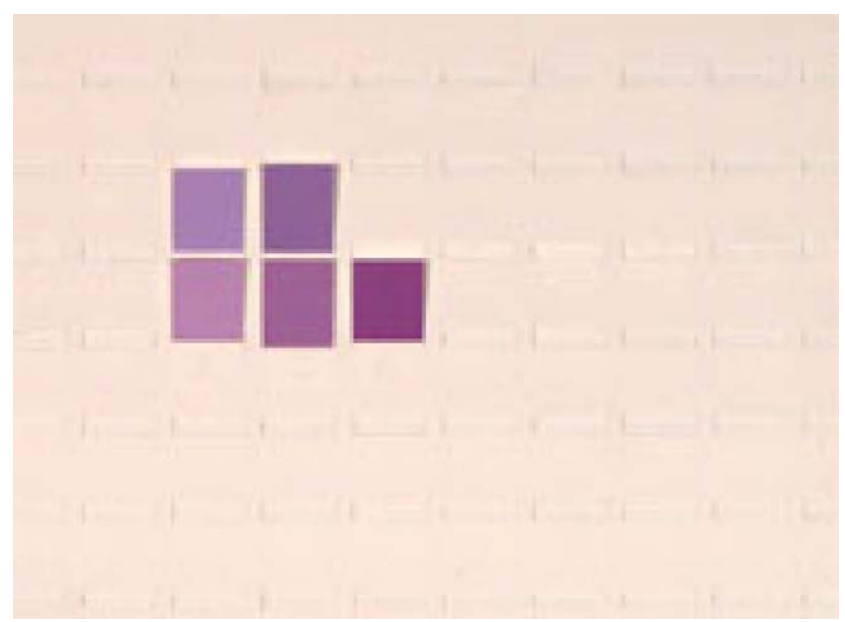

Fig. E.10. Colour samples constituting the range for lilac "leylak". 


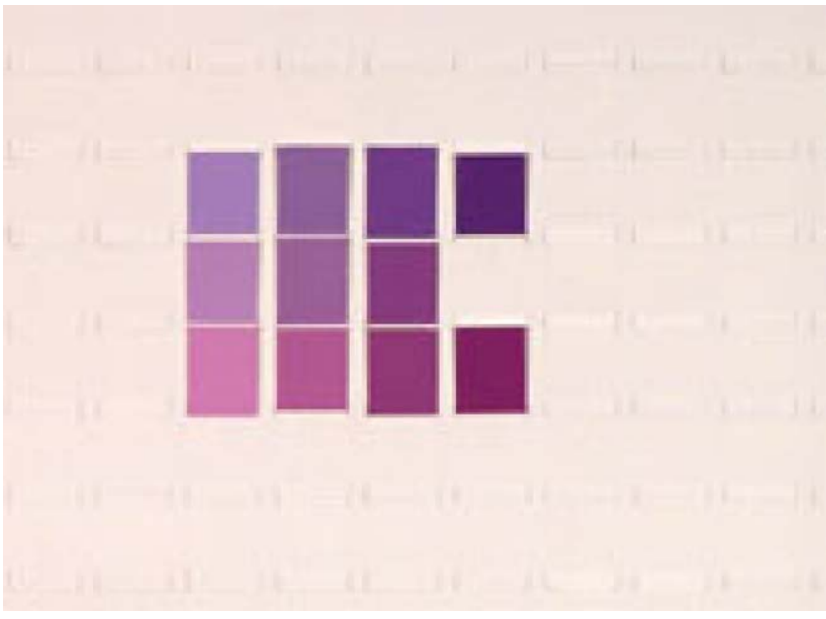

Fig. E.11. Colour samples constituting the range for violet "eflatun".

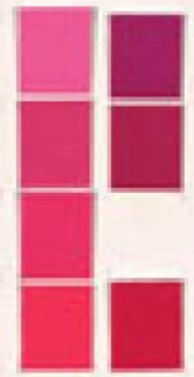

Fig. E.12. Colour samples constituting the range for gypsy pink "çingene pembesi".

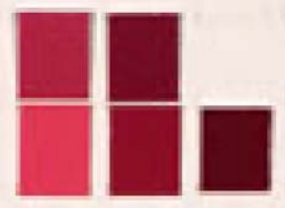

Fig. E.13. Colour samples constituting the range for rose "gül kurusu".

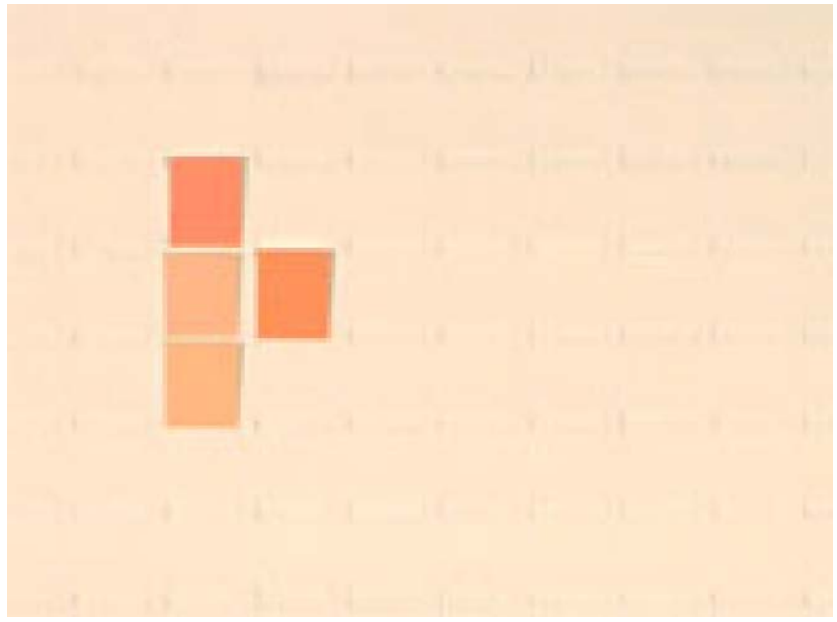

Fig. E.14. Colour samples constituting the range for salmon "yavruağzı".

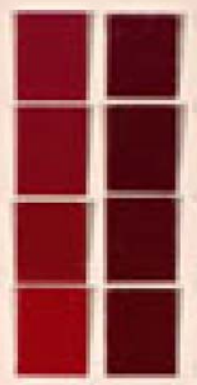

Fig. E.15. Colour samples constituting the range for Bordeaux red "bordo".

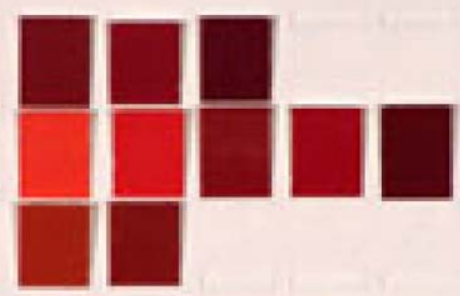

Fig. E.16. Colour samples constituting the range for scarlet "kizll". 


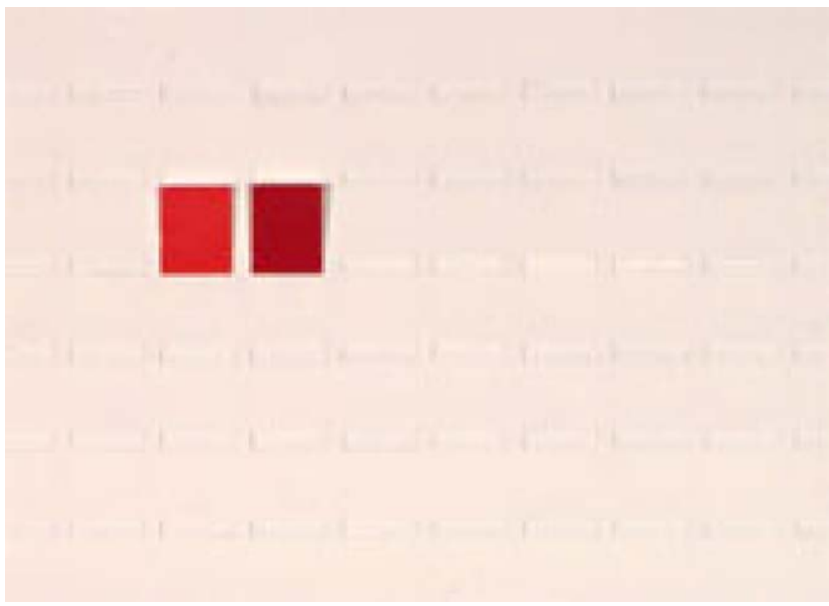

Fig. E.17. Colour samples constituting the range for blood red "kan kirmizisı".

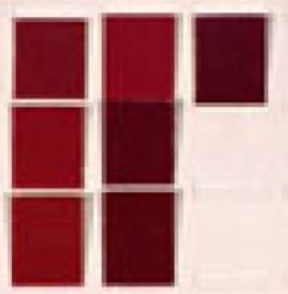

Fig. E.18. Colour samples constituting the range for sour cherry "vișne çürüğü".
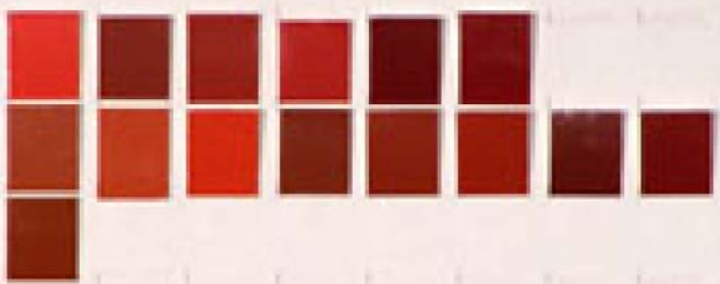

Fig. E.19. Colour samples constituting the range for tile red "kiremit rengi".

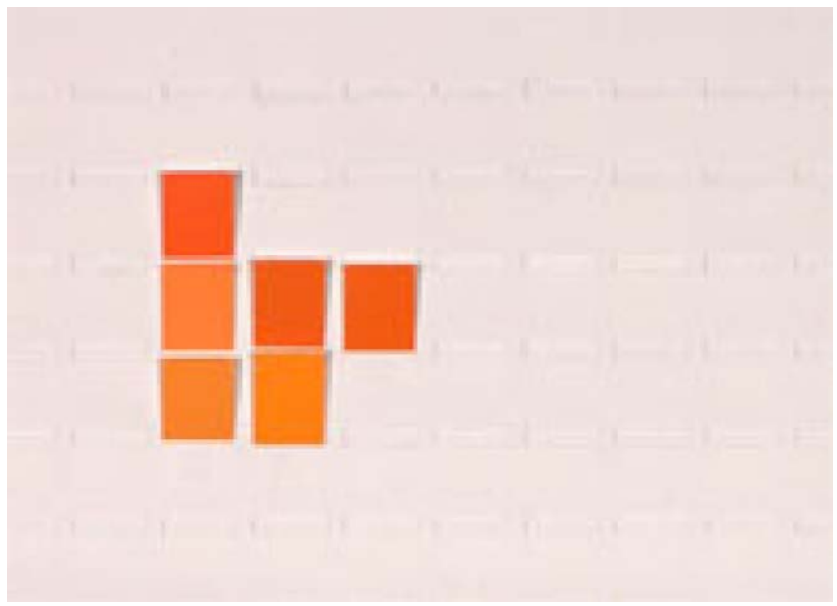

Fig. E.20. Colour samples constituting the range for melon yellow "kavuniçi".

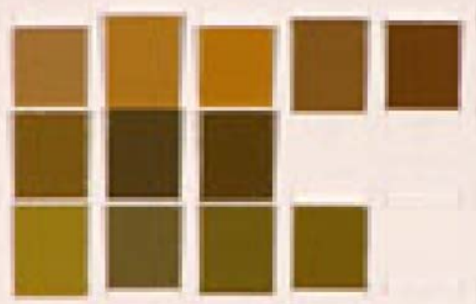

Fig. E.21. Colour samples constituting the range for hazel "ela".

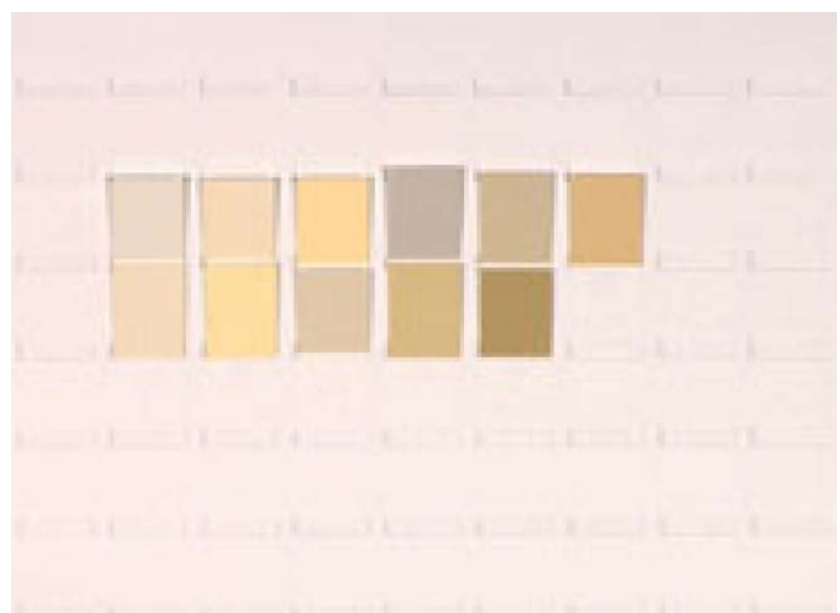

Fig. E.22. Colour samples constituting the range for beige "bej". 


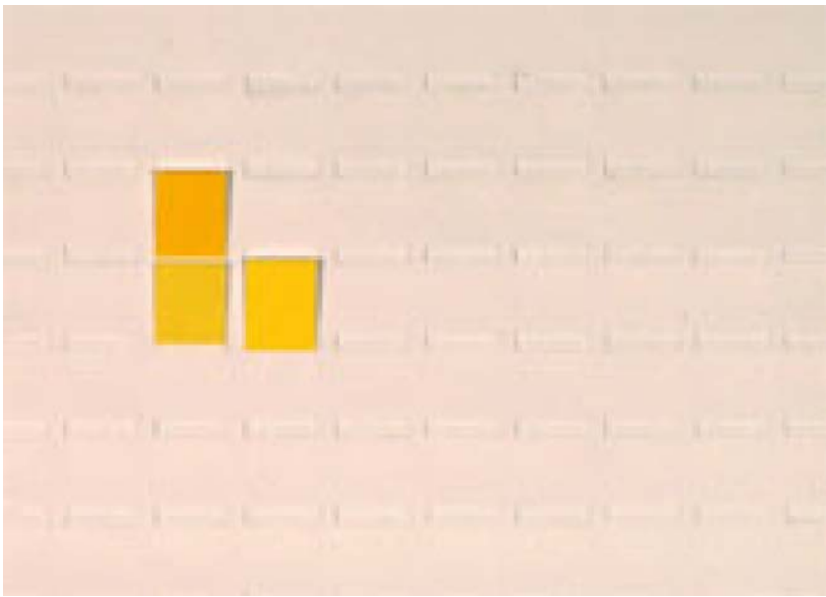

Fig. E.23. Colour samples constituting the range for canary yellow "kanarya sarıs1".

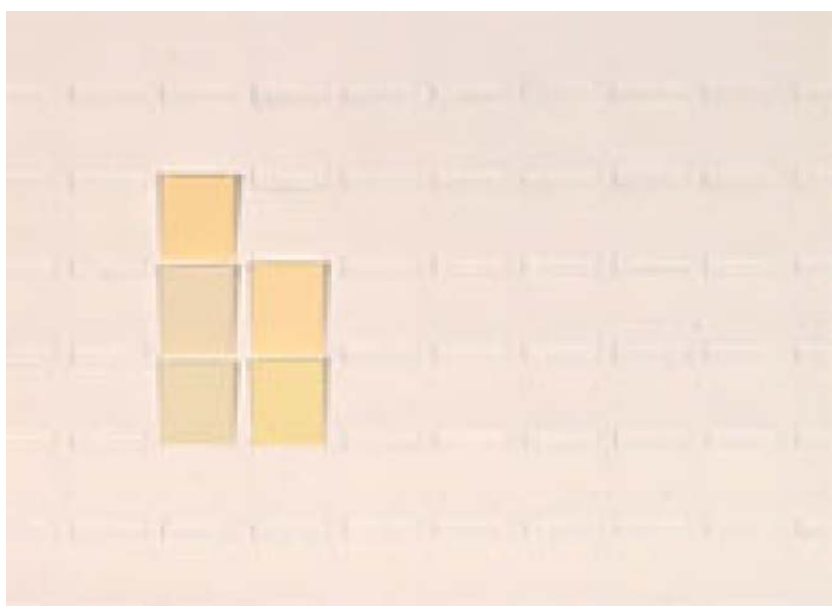

Fig. E.24. Colour samples constituting the range for cream "krem".

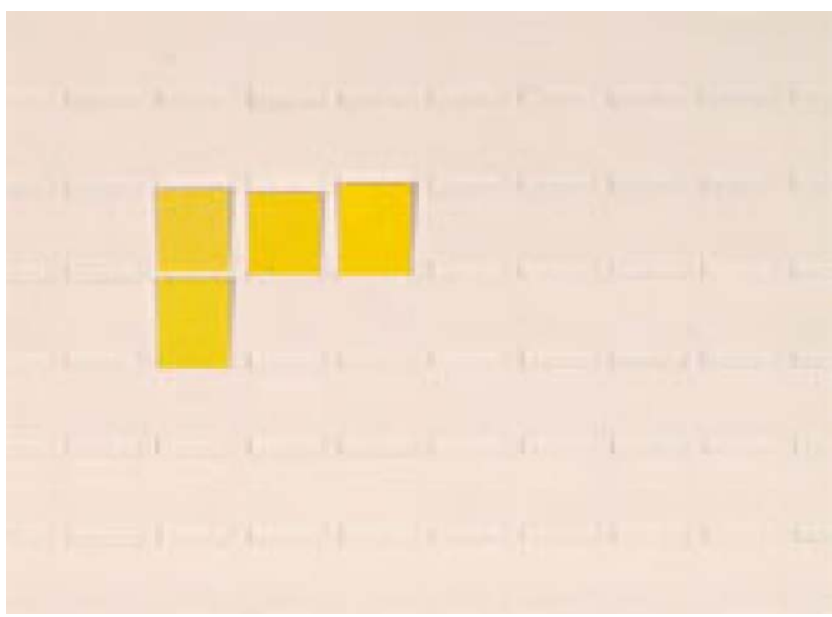

Fig. E.25. Colour samples constituting the range for lemon yellow "limon sarısı".

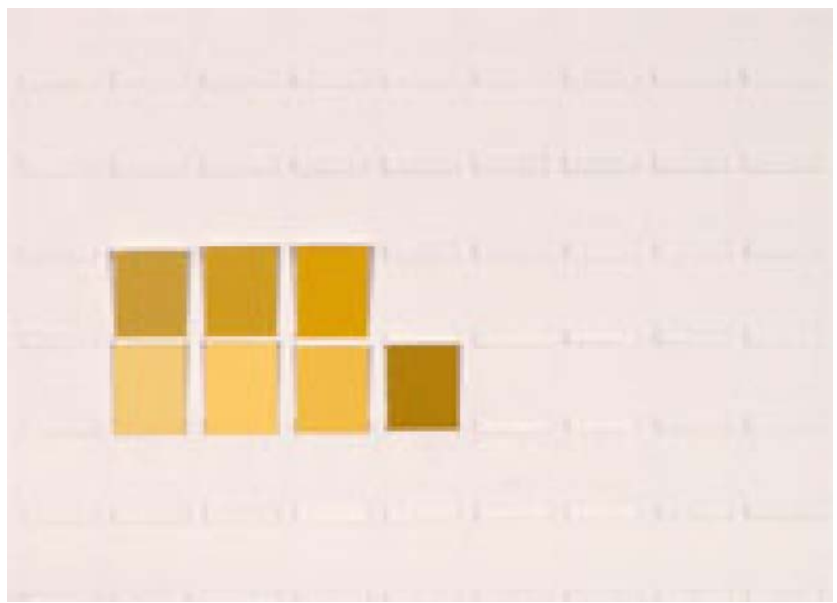

Fig. E.26. Colour samples constituting the range for honey yellow "bal rengi".

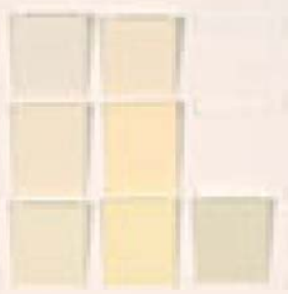

Fig. E.27. Colour samples constituting the range for ivory "fildișis".

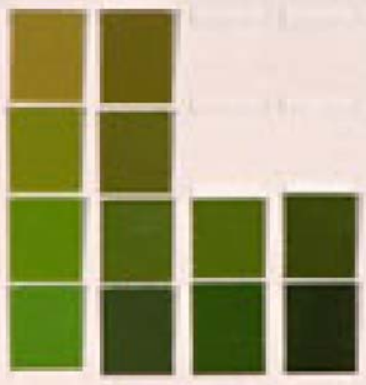

Fig. E.28. Colour samples constituting the range for olive green "zeytin yeșili". 


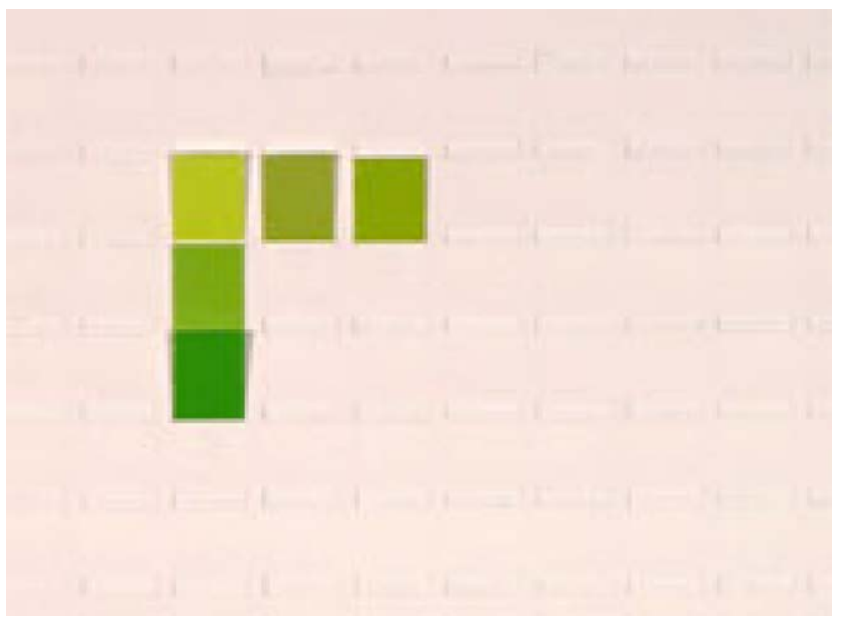

Fig. E.29. Colour samples constituting the range for pistachio green "fistık yeșili".

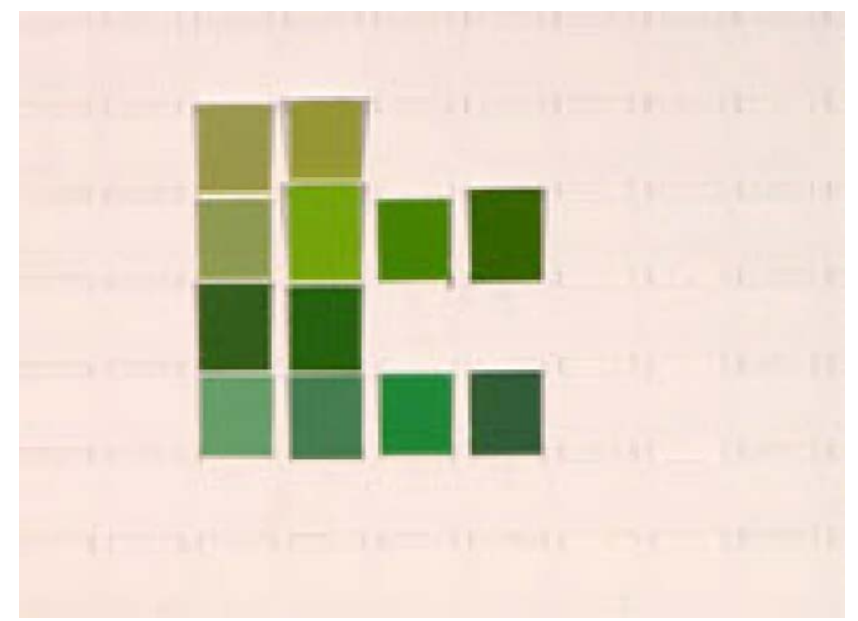

Fig. E.30. Colour samples constituting the range for unripe almond green "çağla yeșili".

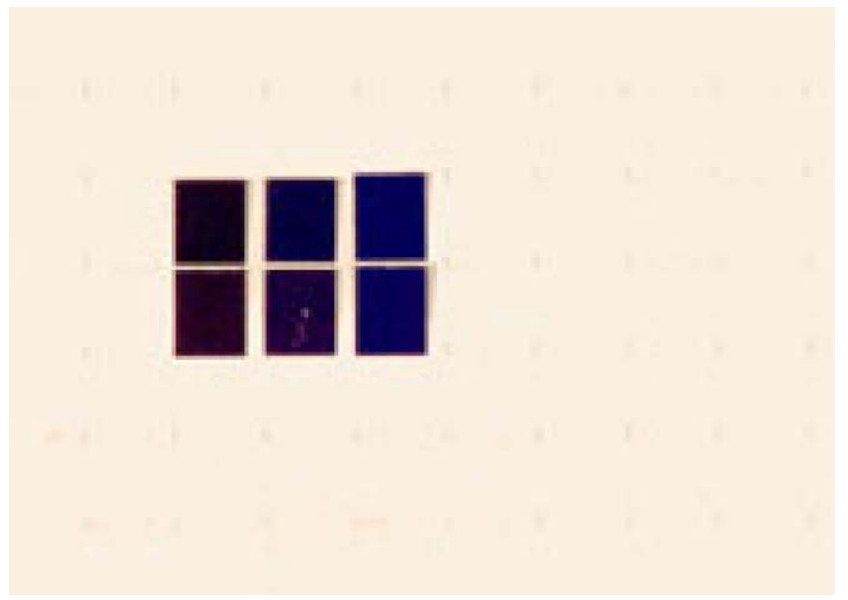

Fig. E.31. Colour samples constituting the range for navy blue

"lacivert".

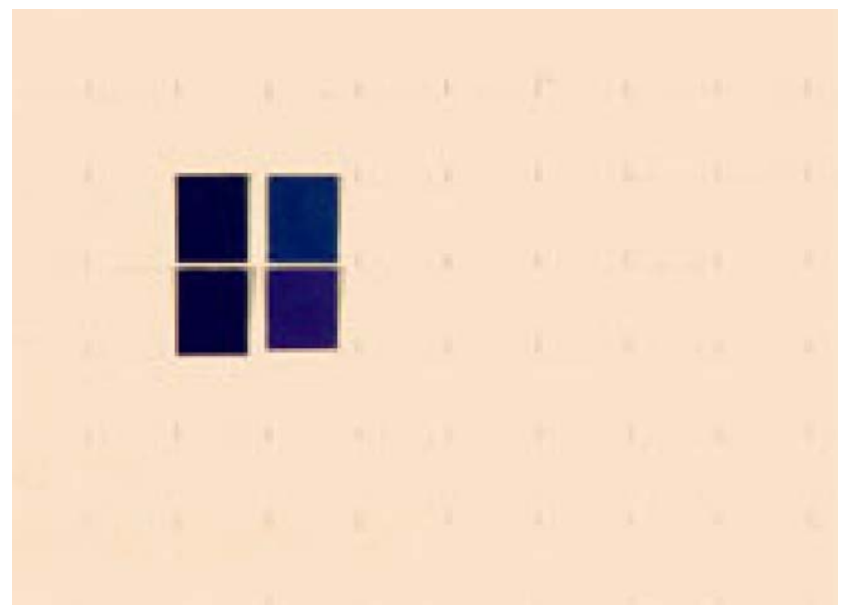

Fig. E.32. Colour samples constituting the range for night blue "gece mavisi".

\section{References}

[1] Qtd in Maffi L, Hardin CL, editors. Color categories in thought and language. Cambridge: Cambridge University Press; 1997. p. 349.

[2] Berlin B, Kay P. Basic color terms. Berkeley: University of California Press; 1969.

[3] Şahin E. Color naming. Diss. Ankara: Bilkent U; 1998. p. 199-201.

[4] DPT (National Planning Office). Ranking of cities according to the rate of migration. Ankara: DPT; 1990.

[5] Munsell book of color: glossy finish collection. Baltimore, MD: Macbeth Division of Kollmorgen Instruments Corporation, 1991.

[6] Davaz A. Dictionary of colour concepts (Renk kavram sözlüğü). İstanbul: Ofset Yapimevi; 1991 (in Turkish).

[7] Kay P, McDaniel C K. The linguistic significance of the meanings of basic color terms. Language 1978;54(3):610-46.

[8] What is the colour of stealth? See life in 8.6 billion colours Panasonic Advertisement, Daily Telegraph Magazine, UK, 23 April 2005. 